\title{
Technological change and women's participation in crop production in Bangladesh
}

\section{Rahman, Sanzidur}

http://hdl.handle.net/10026.1/4038

\subsection{7/097185249800200204}

Gender, Technology and Development Informa UK Limited

All content in PEARL is protected by copyright law. Author manuscripts are made available in accordance with publisher policies. Please cite only the published version using the details provided on the item record or document. In the absence of an open licence (e.g. Creative Commons), permissions for further reuse of content should be sought from the publisher or author. 


\title{
TECHNOLOGICAL CHANGE AND WOMEN'S PARTICIPATION IN CROP PRODUCTION ACTIVITIES IN BANGLADESH*
}

\author{
by \\ Sanzidur Rahman \\ $\mathrm{Ph}$.D. Candidate \\ Regional and Rural Development Planning \\ Human Settlements Development Program \\ School of Environment, Resources and Development \\ Asian Institute of Technology \\ Bangkok, Thailand
}

and

\author{
Jayant K. Routray, Ph.D. \\ Associate Professor \\ Regional and Rural Development Planning \\ Human Settlements Development Program \\ School of Environment, Resources and Development \\ Asian Institute of Technology \\ Bangkok, Thailand
}

December, 1997

\footnotetext{
- The present paper is extracted from the first author's ongoing Doctoral Dissertation Research in the field of Regional-Rural Development Planning at the School of Environment, Resources and Development (SERD), Asian Institute of Technology (AIT), Bangkok, Thailand.
} 


\begin{abstract}
There is a dearth of knowledge on the employment effect of modern agricultural technology on rural women in Bangladesh. The present study provides a systematic estimate of women's participation in crop production activities and examines their influence in the diffusion of modern technology and their participation in hired labor market. Farm-level inputoutput data of fourteen crop groups is taken from two intensive surveys, crop years 1989 and 1996, respectively, in three agro-ecological regions of Bangladesh.

Findings suggest that the prevailing claim that women are involved only in post harvest processing of crop production is an underestimation of women's contribution to agricultural production. Women's share of total labor requirements is between 10 - 18 percent in foodgrain production and between $6-48$ percent in non-cereal crop (lowest for jute and highest for vegetables) production. Increased demand for labor owing to technological change was almost entirely met by hiring male labor, revealing that women were deprived from reaping full benefits from modern agricultural technology. The few women, who were hired, were paid significantly lower wages; revealing unequal opportunities and a lack of bargaining power for women in the hired labor market. Analysis of modern technology adoption behavior revealed a significant negative association between working women family members and modern variety adoption rate, implying a lack of participation of women in technology adoption decisions. Analysis of determinants of labor demand revealed negative association of working women family members with labor demand, implying that increased demand for total labor is substituted from female family labor thereby increasing their workload.

A decentralized crop diversification policy toward non-cereal crop production would promote women's gainful employment. Also, a policy of equal minimum wage for men and women is urgently needed. Moreover, building up of human capital by providing gender sensitive educational programs facilitated through a collaborative effort between government and NGOs could be a positive step toward achieving the goal of balanced development in the long run.
\end{abstract}




\section{Introduction}

Rural women in Asia play a major role in the agricultural sector particularly in post harvest processing. Since the advent of the 'Green Revolution' (popularly coined as 'new seed-fertilizer-water' technology) in Asia from the mid-sixties, foodgrain (rice and wheat mainly) production grew at a remarkable rate owing to a dramatic increase in productivity gains per unit of land as well as a sharp increase in cropping intensity. Associated with this productivity growth is the increased demand for labor, particularly in the Asian region whereis the nature of rice and wheat based Green Revolution technology is labor intensive. The scope of mechanization in the production arena included only the provision of water for irrigation and to some extent for land preparation. However, a major shift in technology occurred in the post harvest processing sector, as the introduction of rice mills has dramatically displaced employment opportunities for rural women involved in manual husking of rice grains. Ahmed (1982) estimated that rice mills displaced 29 percent of the total husking labor. Almost all hired labor displaced was women who have limited alternative employment opportunities. His crude nationwide estimate reveals that, if rice mills are made available throughout the country, a total of 45 million person-days of hired labor would be displaced leading to a reduction of rural poor's income of about $\mathrm{Tk}^{1} .450$ million at 1982 estimates.

Alauddin and Tisdell (1995), observing historical data for Bangladesh, claimed that though significant employment gains have resulted from Green Revolution technologies in Bangladesh, the employment generating effect of Green Revolution has been slowing down in recent years, showing little prospect for increased absorption. Also, there is little prospect of a major turning point in labor absorption in the non-farm sector to lead to a successful industrialization as observed in East Asian regions, thereby providing a gloomy future for 
Bangladesh. A similar conclusion has also been arrived at by Osmani (1990). He noted that the drastic fall in the total labor force in agriculture is not an indication of a turning point ${ }^{2}$ but rather the consequence of increasing work-sharing arrangements and consequent decline in average productivity per worker. He claimed that the true nature of the shift gets revealed in areas where technological change has opened up new opportunities for gainful employment in agriculture. In these areas, a reverse flow of surplus labor from the non-farm sectors to farm activities, are observed.

As the employment opportunities for rural women are closing in the post harvesting processing sector and the non-farm sector is highly stagnant, the alternative lies in actively involving them directly in crop production activities. In this respect, it is worth mentioning that the gender division of labor in Bangladesh agriculture is strictly demarcated with women being responsible for most of the agricultural work within the household and not generally allowed to undertake field or market work (Begum, 1985; and Abdullah, 1985). However, the contrasting version is also evident. Zaman (1995) observed that village women are working in fields with men as agricultural wage laborers. She noted that women not only participate in rice crop production and processing but is also involved in the production and processing of other major crops such as sugarcane, jute, wheat, and other winter crops.

A large number of studies were undertaken in evaluating the impact of the Green Revolution in Bangladesh agriculture (e.g., Hossain, 1989; Ahmed and Hossain, 1990; Hossain et al. 1990; and Alauddin and Tisdell, 1991). Though most of these studies explicitly examined the employment effects of modern agricultural technology they did not incorporate gender dimension in their analyses. Furthermore, there is a dearth of knowledge about the employment effect of modern agricultural technology for rural women and studies dealing 
with the issue remain confined in post harvesting processing activities (e.g., Begum, 1985; and Abdullah, 1985). As such, no systematic estimate of the gender division of labor use for agricultural crops is available for Bangladesh. Also, the time-use approach used in studies dealing with gender roles has examined daily workloads by activities, but has not provided the total labor input used for specific crops by gender (e.g., Zaman, 1995).

The present study, therefore, attempts to contribute to the existing body of literature by estimating the extent of women's participation at different stages of crop production activities for major crop groups, and examining their influence in the diffusion of modern agricultural technology and participation in the hired labor market.

\section{Methodology and Data}

\subsection{Employment Effects of Technological Change: Theoretical Framework}

Prior to the analysis of the employment effects, a brief on the theoretical framework of the labor use effect of technological change would be worthwhile. The impact of three basic types of technological change and their impact on labor use are presented in Figure 1. In Figure 1, point $\mathrm{A}$ is the combination of factors used with the old technology. The three new isoquants $\mathrm{D}, \mathrm{B}$, and $\mathrm{C}$ represent labor-saving, neutral and labor-using technologies, respectively, that are capable of producing the same level of output utilizing cost minimization principles. Moreover, labor productivity increases in all three cases. Due to the variation of factor proportions, the demand for labor also varies (Unnevehr and Stanford, 1985).

Figure 2 shows the impact of labor demand from three types of technological change at an individual household level. Under a given set of prices of inputs and output, $\mathrm{L}_{\mathrm{O}}$ amount of labor is used for the traditional (old) technology. With either a neutral or labor-using shift in 
the production function, it will be profitable for the household to employ additional labor to produce more output.

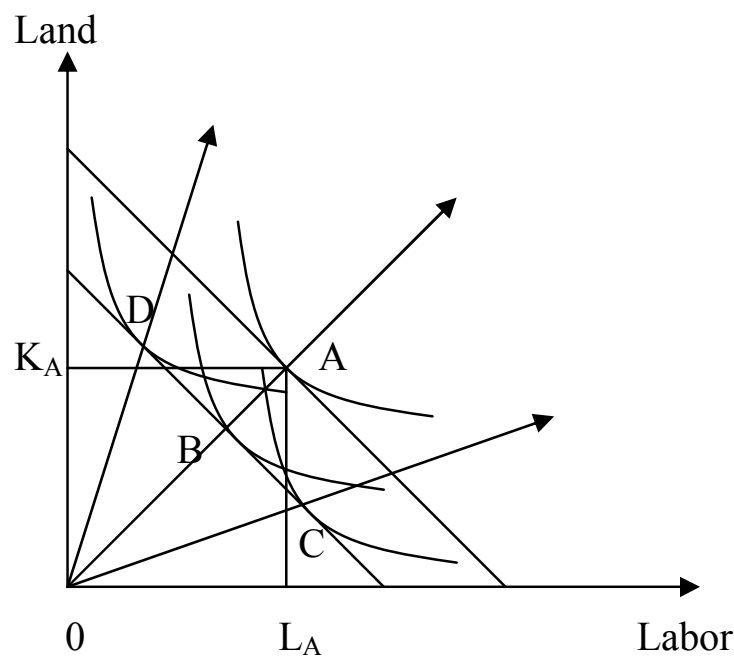

Figure.1. Technological Change and Factor Proportions.

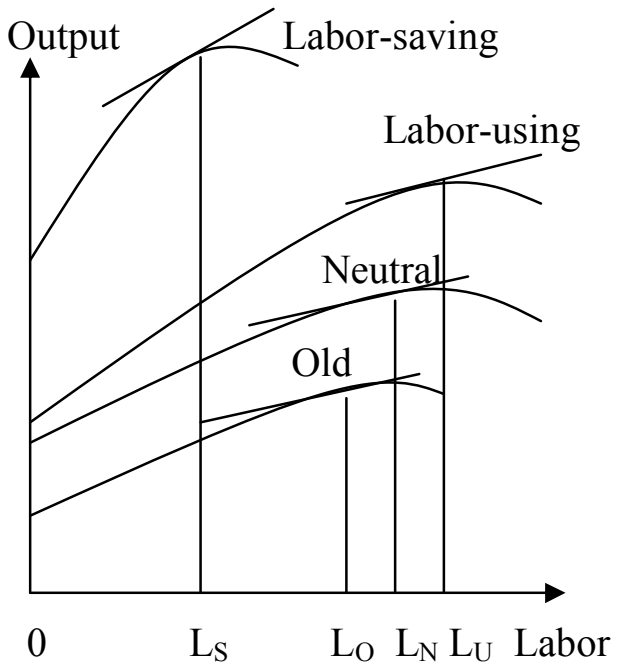

Figure.2. Technological Change and Labor Use.

Source: Adapted from Unnevehr and Stanford (1985).

This additional demand for labor owing to labor-intensive technological change can be absorbed by either increasing the supply of family labor or by hiring-in labor. Experience suggests that in rice-producing districts of India, women's work participation is high in farm families where hired labor is used less and much lower where hired labor accounts for a large part of the labor force (Boserup, 1989). Agrawal (1994), citing South Asian experiences, noted that significant change occurred in the gender distribution of labor in wet rice cultivation. Women's role, which was primary in the shifting (jhum) cultivation system, has been reduced to secondary status in plough based permanent cultivation systems. Boserup (1989) views this reduction of women's role in agriculture as beneficial for women members in farm families whose workload is substantially reduced owing to the increased availability of hired labor. The focus of the present study is not to challenge these arguments; rather it is to examine the 
composition or gender distribution of the hired labor, which supposedly reduces the workload of women farm family members. The notion is that if the increased demand for hired labor is met by hiring female labor then their displacement from the labor force owing to the postharvest technological shift can be mitigated to some extent.

\subsection{Types and Sources of Data}

The primary data for the study pertain to two intensive farm-surveys conducted at two periods, first in crop year 1989, covering two agroecological regions ${ }^{3}$, and the second in crop year 1996, covering the first two regions and an additional agroecological region. In the first period, complete household census of eight villages from Jamalpur Sadar Thana of Jamalpur region representing wet agroecology and six villages from Manirampur Thana of Jessore region, representing dry agroecology were conducted. In the second period, selected representative samples from the aforementioned villages and the additional seven villages from Matlab Thana of Comilla region, representing the favorable and agriculturally developed zone were collected. Therefore, total sampled households for the first period stand at 1,755, and in the second period 406 respectively. A test for representativeness based on land ownership categories ${ }^{4}$ revealed that the distribution of households by land ownership status of the second period largely represents the size distribution of households of the first period.

Details of crop input-output data were collected in both periods. However, only the first survey period, i.e., the survey of crop year 1989, contains labor input data for each agricultural operation and for specific crop production activities classified by gender. Therefore, part of this study is based on 1989 data and part on 1996 data. 


\section{Results and Discussion}

\subsection{Attitudinal Change in Valuing Women's Work at the Macro Level}

Starting from the early sixties until the late eighties (e.g., Population Censuses of 1961, 1974, and 1981, and Labor Force Surveys of 1983/84, 184/85, and 1985/86) there has been a consistent under estimation of women's involvement in the Civilian Labor Force (CLF). Women's participation in CLF increased from 0.9 million in 1961 to 3.2 million in 1986 while for the same period men's participation increased from 16.0 million to 30.5 (BBS, 1995). However, in the Labor Force Survey of 1989, the number of women in the labor force recorded a seven-fold jump from its 3.2 million level in 1985/86 to 21.0 million in 1989 (BBS, 1995). The reason for such a jump is not due to any dramatic increase of employment opportunities for women rather, it is due to change in the definition of women's work. Furthermore, this increase was observed largely for women in rural regions, implying the growing realization of the value of women's work, particularly in rural areas.

\subsection{The Study Regions: Basic Characteristics}

Of the three study regions, Jamalpur region is located within Jamalpur Sadar Thana (central administrative sub-district) which in turn is located in the southeastern part of Jamalpur district. The study area is about $11 \mathrm{~km}$ by road from district headquarters and 182 $\mathrm{km}$ northwest from the capital of Dhaka. The Jessore region is located at Manirampur Thana in the southern part of Jessore district. The study area is about $20 \mathrm{~km}$ by road from district headquarters and $294 \mathrm{~km}$ southwest from the capital of Dhaka. The Comilla region is located at Matlab Thana in the southeastern part of Chandpur district. The study area is about $18 \mathrm{~km}$ by road from Chandpur district headquarters and $120 \mathrm{~km}$ southeast from the capital of Dhaka. 
Comilla region has the lowest amount of owned land per household ( $0.53 \mathrm{ha})$ with the highest family size (7.0 persons/household). Jessore region has the highest amount of owned land per household ( $0.90 \mathrm{ha})$ followed by Jamalpur $(0.80 \mathrm{ha})$. The family size for these two regions are 6.7 and 5.4 persons/household, respectively. The highest proportion of modern technology diffusion is in the Jamalpur region, with 75 percent of the land under cultivation with modern variety of rice and wheat and 59 percent of the land under irrigation during the crop year 1996. The area under cultivation of modern varieties for Jessore and Comilla region is 56 percent and 59 percent, respectively. The area under irrigation for these two regions is 59 percent and 47 percent, respectively.

\subsection{Labor Input in Crop Production by Gender}

Zaman (1995) provided details of women's daily time use in postharvest activities, animal care, field agriculture and wage labor, by land ownership classes. Her results showed that both women of small and landless classes work in field agriculture and only landless women work as wage labor while postharvest activities and animal care was done by women of all four classes; rich, middle, small and landless, respectively. She estimated that average hours spent per day for agricultural work is 3.1 hours for women and 5.1 hours for men, respectively. Though her study provided comprehensive time use for men and women in agricultural work, it did not provide an estimate of total labor input required for individual crops classified by gender.

In this study, labor input data by gender differentials were reported for 14 crop groups ${ }^{5}$ which in turn consist of about 35 different crop types covering almost the total cropping system of the study regions. The total number of sample observations for crop year 1989 is 8,102 and crop year 1996 is 1,448 , respectively. It should be noted that though Bangladeshi 
farmers produce large numbers of crops, rice (both local and modern varieties) alone constitutes over 75 percent of the gross cropped area. In the present study, rice of all varieties of all three seasons (Aus, Aman and Boro season, respectively) constitutes 80 percent of the gross cropped area. The cropping intensity of the sample households is estimated at 172.8 which is very close to the national estimate of 179.2 for the crop year 1992/93 (BBS, 1995).

The human labor input for crop production ${ }^{6}$, classified by gender and by sources of supply, is presented in Figure 3. It is clear from Figure 3 that women's labor input varies substantially across crop groups. The women's involvement in foodgrain (all varieties of rice and wheat) production is between $10-18$ percent, while for non-cereal crops, such as pulses, oilseeds, spices, cotton and vegetables, the range is above 20 percent. The highest involvement is in vegetable production (about 48 percent of total labor requirement) which is also known as kitchen garden crops. This finding, therefore, suggests that the claim that women's labor is actively utilized only at the post harvest processing stage in Bangladesh is an underestimation of women's contribution to agriculture. The estimate for women's labor input in foodgrain production resembles Boserup's (1989) estimate. She estimated that involvement of women in agricultural production systems in Asia (Bangladesh not included) is less than 20 percent.

A comparison of labor input data of the present study with data from other evaluation studies of the Green Revolution reveals that inclusion of women's labor separately in labor accounting does not seriously overestimate the total labor requirements of crop production (Figure 3). However, excluding women's labor in labor accounting seriously under-mines their important role in agricultural production.

Limiting analysis to labor use only at this point can lead to misleading of conclusion on predicting the market for hired women's labor requirements. A close look at the columns of 
hired labor input in Figure 3 will clarify the matter by revealing the dismal scenario of hired women's labor. The figures for hired women are practically nil for rice, marginally positive for wheat, and less than 10 percent for the non-cereal crop production. Only cotton production, a specialized crop grown in pockets of Jessore region, involves the large amount of hired women labor. This indicates that the labor-intensity argument of modern agricultural technology remains true in the sense that the proportion of labor use is substantially higher for modern varieties of rice and wheat (Figure 3). However, the distributive justice of this increased demand for labor remains skewed in favor of men. The increased demand for labor owing to rapid technological progress in foodgrain production was absorbed in two ways, first by an increased supply of women members from farm families, and second by hiring-in male labor alone. Therefore, women are affected in two ways from this technological change in agriculture. First by an increased workload of intensive agriculture if they belong to a farm family (Figure 3), and second by being displaced from the hired labor market on two counts, from the post-harvest sector as well as the crop production sector. Though it is encouraging to note the increasing trend in the hired labor component in production of all crops in recent years $^{7}$, this trend leaves little for the growing mass of landless rural women as only men are hired to meet the increased demand. Most of the past evaluation studies of labor market effects of technological change in agriculture (e.g., Hossain, 1989; Ahmed and Hossain, 1990; Hossain et al. 1990; and Alauddin and Tisdell, 1991) bypassed this notion of persistent gender inequality in reaping the benefits of Green Revolution technology.

The breakdown of women's labor input by agricultural operations is presented in Figure 4. Though a major portion of women's labor input goes into threshing operations for foodgrain crops, about $5-10$ percent is involved in harvesting operations, weeding and 
fertilizing. For non-cereal crops, the extent of involvement is wider, in all types of agricultural operations, such as, in potato, spices, and vegetables production which again challenges the claim of women being involved only in post harvest processing of agricultural crops.

\subsection{Gender and Adoption of Modern Agricultural Technology: A Multivariate Regression Analysis}

A number of factors, technical and socio-economic, may influence the adoption decisions of farmers (Hossain, 1989). However, the relationships of these factors with the adoption decision cannot be determined a priori. Farm size, availability of irrigation, need for working capital, tenurial status, subsistence pressure, access to infrastructural facilities, soil fertility, etc. may influence adoption decisions. In addition to these factors, women's participation as working family members may influence adoption decisions. Few of the past studies noted above explicitly highlighted the role of gender in analyzing determinants of modern technology adoption.

In this study, the following equation was fitted to the household level data to explain the extent of adoption of modern agricultural technology and factors influencing the adoption decisions:

MVF $=\mathrm{f}(\mathrm{OWNLND}$, IRRIG, RENT, LBR, EDUCH, NAGINC, AGCRDIT, AMLND, INFRA, SOIL, FP, WAGE, ANMPRIC, FARMASET, FAMYSIZE, WORKING, WORKWOM)

MVF = proportion of cultivated land under modern varieties of rice and wheat,

OWNLND = amount of land (ha) owned by the household,

IRRIG = proportion of cultivated land under irrigation,

RENT = proportion of cultivated land rented-in,

EDUCH = completed years of formal schooling for the head of household,

LBR = amount of land cultivated per agricultural worker (ha),

NAGINC = income ('000 Tk.) from non-agricultural sources of the household,

AGCRDIT = amount of agricultural credit ('000 Tk.) borrowed by the household,

AMLND = amount of land cultivated (ha) by the household,

INFRA $^{8} \quad=$ index of under development of infrastructure,

SOIL $^{9}=$ index of soil fertility environment, 
$\mathrm{FP}=$ fertilizer price relative to price of rice and wheat at farm level,

WAGE = labor wage relative to price of rice and wheat at farm level,

ANMPRICE = animal power price relative to price of rice and wheat at the farm level,

FARMASET = value of farm capital ('000 Tk.) excluding land asset,

FAMYSIZE = number of family members in the household,

WORKING = number of working members in the household,

WORKWOM = number of working women members in the household,

As data of the dependent variable is observed in the range between 0 and 100 , the values are censored at both tails. The most appropriate estimation technique for such case is the Tobit (two limit probit) procedure (Hossain, 1989; Ahmed and Hossain, 1990; and Hossain et al. 1990). For the present study, both OLS (Ordinary Least Squares) and Tobit estimation procedures were applied to the data ${ }^{10}$. The estimated parameters of the model are presented in Figure 5 with asymptotic t-ratio in the parentheses.

Figure 5 reveals that both models provide similar results. The most significant factor that influences modern technology adoption is the availability of irrigation reflected by the highest t-value. The index of underdevelopment of infrastructure also influences adoption decision implying that the under developed regions tend to adopt modern technology. This might be due to constraints imposed by the underdeveloped infrastructure to switch to other non-farm income generating activity. This notion is supported by the non-agricultural income of the household variable, which is negatively related to modern technology adoption. Hossain et al. (1990) also observed that adoption rate is higher in areas with unfavorable land endowments and/or lower non-farm employment opportunities. The negative relationship between adoption rate and non-agricultural income implies that lower non-agricultural income opportunities will result in higher adoption, which is parallel to the implication of Hossain et al. (1990). 
In the OLS model, the soil fertility index is significantly positively related with adoption, implying that the better the soil fertility, the higher will be the adoption of modern varieties, which conforms to a priori expectations. The relative price of animal power service is significantly positively related with adoption implying that as the price of animal service becomes expensive relative to price of rice, the adoption of modern technology will increase. This is expected as net return from modern variety is much higher than from the local variety (Hossain et al. 1990; Hossain, 1989) while the cost of animal power service for land preparation is similar, which makes it profitable to switch to modern varieties. A comparison of selected relevant indicators with other study (BIDS survey, 1987) reveals similarities as well as dissimilarities in the roles of each variable in determining adoption decisions.

It is interesting to note that though total number of working members in a household is positively related with modern technology adoption, the number of working women members is significantly negatively associated with it. The t-value is third highest, just after irrigation and infrastructure variable. This indicates a lack of access for women in the decision making process, in the present context, with respect to modern agricultural technology adoption decisions.

\subsection{Gender, Rural Labor Market and Employment}

Though it is widely recognized that modern technology adoption directly influences the distribution of income across all classes of farmers and geographical regions, the scale neutrality of modern technology has been seriously criticized resulting in diverse evaluations. This is evident in the conclusion drawn by Freebairn (1995) from his analyses of 307 evaluation studies. However, researchers argue that modern technology adoption may also have indirect effects through the operation of markets, particularly the hired labor market, 
where those adversely affected by the advent of modern technology would benefit from a redistribution of income through increased wages owing to increased labor demand. For example, studies by Hossain (1989), and Hossain et al., (1990) concluded that modern technology diffusion increases the size of the labor market with increased demand for hired labor. Also, a change in the composition of labor takes place from low-wage attached labor to high-wage casual labor.

The present study is not only set to identify the present day validity of this indirect effect argument of technological change but also attempts to analyze the influence of women in the hired labor market. As a first step towards such an attempt, the actual farm-level wages paid for hired labor for both men and women for the crop year 1989 are presented in Figure 6. The level of inequality in wage payments for women is clearly demonstrated in Figure 6 . The mean daily wage rate for men is $32 \mathrm{Tk} /$ day while for women it is $20 \mathrm{Tk} /$ day. Though there is a significant wage differential (about $2.2 \mathrm{Tk} /$ day) for men across region, the inequality against women remains constant with a difference of $11 \mathrm{Tk} /$ day as compared to men's wage.

\subsubsection{Determinants of Labor Demand: A Multivariate Regression Analysis}

It is already evident from Figure 3 that modern varieties of rice and wheat production utilize more hired labor than traditional varieties. In order to rigorously test this hypothesis and to identify the influence of women in labor demand, a multivariate analysis was performed at the household level. The following equation was fitted to the data:

DLBR $=\mathrm{f}($ AMLND, MVAREA, RENT, WAGE, INFRA, SOIL, SUBP, WORK, WORKW, EDUC)

DLBR = the number of days of labor used in crop production

AMLND = the amount of land cultivated (ha)

MVAREA $=$ the amount of land allocated for modern varieties of rice and wheat (ha)

RENT = the amount of land rented-in (ha)

WAGE $=$ the wage rate paid by the farmer ( $\mathrm{Tk} /$ day) 
INFRA $=$ the index of underdevelopment of infrastructure

SOIL $=$ the index of soil fertility

SUBP = subsistence pressure measured as number of family members in the household

WORK = number of working member in the family

WORKW = number of women working member in the family

EDUC = number of completed years of schooling of household head

Both OLS and Tobit estimation procedures were applied to data on hired labor use and only OLS procedure on total labor use at the household level. The estimated parameters are presented in Figure 7 with asymptotic t-ratio in the parentheses.

The fit is remarkable for both models for hired as well as total labor demand as indicated by high values of adjusted R-squared, F-ratio, and significance of variables. The results are closely comparable to a similar estimates computed on crop data of the IFPRI/BIDS survey (1982). It is clear from Figure 7 that despite a gap of 15 years between these two surveys, the nature of labor demand remains strikingly similar. This reveals the stagnant nature of agricultural production practices in Bangladesh.

Labor wage remains an important factor in determining labor demand with its strong negative influence, both for hired labor as well as total labor (Figure 7). The cultivated area and area under modern varieties are significantly positively associated with labor demand. However, the tenurial status is significantly negatively associated with hired labor but positively with total labor. This is because land rent in Bangladesh ranges from $40-45$ percent of gross value of agricultural production (Hossain et al. 1990), therefore, hiring more wage labor would seriously depress any profit from crop production. The situation was the same 15 years ago, as evident from the comparison study.

The index of underdevelopment of infrastructure also operates in the similar way. The higher the level of infrastructural development, the higher will be the demand for hired labor 
as members of the households are expected to engage more in non-farm activities leading to the shortage of family labor available for crop production. The education level of the household head is positively associated with hired as well as total labor demand. The comparison study also revealed the same results.

The soil fertility environment appears to influence labor demand significantly. The higher the soil fertility, the lower will be the demand for hired as well as total labor. This is expected, as high soil fertility would require less labor input for all operations. The subsistence pressure and total number of working members is negatively associated with hired and total labor demand consistent with the a priori expectation.

It is interesting to note that, the total number of working women in the family negatively influences the total demand for labor. The sign of the coefficient is consistently negative in the present study as well as in the comparison study. This reveals the consistency of important role that women play by substituting for hired labor from the family in agricultural production in Bangladesh. This finding strengthened the notion that the workload of women members of farm families increased in order to mitigate the increased demand for labor required for modern agricultural technology.

\section{Summary, Conclusions and Policy Implications}

Technological change is an important factor in economic growth and development. Historical experience suggests that technology, by raising productivity of factors (e.g. labor, capital, land and other natural resources), has played an important role in economic growth. Agriculture constitutes the major source of livelihood in Bangladesh. The agricultural sector accounts for more than 50 percent of national income and employs two-thirds of the labor force. Alauddin and Tisdell (1991) note that if supporting activities like transport and 
marketing of agricultural products are taken into account, the share of agricultural sector GDP is likely to be over 60 percent of total GDP.

The results of the present study confirm that the claim that women are actively involved only in post harvest processing of crops is an underestimation of women's contribution to agricultural production. The share of women's labor is about 20 percent in foodgrain production, and higher for non-cereal crops, particularly vegetable production where the share is about 48 percent. This has profound implications for agricultural diversification strategies, which are under scrutiny owing to adverse impacts associated with diffusion of modern agricultural technology in other regions of Asia, as indicated by Shiva (1991). Promotion of vegetable production would increase involvement of women in agriculture. Agricultural diversification also has high potential to promote women's employment as hired labor. In Bangladesh, some NGOs (non-governmental organizations), such as BRAC, Proshika, and ASA, have been promoting kitchen gardening (vegetable production around the homestead) by actively involving their women group members for years. For example, BRAC provided training on vegetable production to about 26,000 of its group members; mostly women, by 1993 . An estimated 15,755 members cultivated 2,072 ha of land with vegetables (BRAC, 1993).

The present paper, by systematically documenting gender roles in crop production, modern technology adoption decisions, and market demand for labor, shows discrimination against women for their labor contribution despite the significant role that they play in the agricultural sector. Extraction of relevant findings (but not highlighted in their studies) of other comparative evaluation studies on impacts of technological change also supports this notion. Though technological progress in Bangladesh agriculture had the positive impact in 
increasing employment, the benefit of this increased employment has been almost entirely absorbed by men. The practice of hiring female labor is minimal, and when hired, women are paid very low wages. Agrawal (1994) noted that women's ability to bargain in the labor market is critically affected by gender ideology and practices. She argued that ownership and control over land resources would be one effective means to improve women's bargaining power in the labor market. In fact, there is an urgent need to prevent discrimination against women, particularly rural landless women, who line up in the hired labor market, by devising and effectively implementing the policy of minimum equal wage rates for both men and women.

At the household level, the contribution of labor to agricultural production by women will be beneficial, if and only if, the intra-household distribution of income among family members is improved. This to a large extent depends on the bargaining power of the women members within the family which in turn depends on the relative strength of her fall-back position (outside options) as examined in Sen's (1990) work. Such analysis is beyond the scope of the present study. Yet it is important to note that technological change in Bangladesh increased farm family income substantially (Hossain, 1989; Ahmed and Hossain, 1990; and Hossain et al. 1990). However, it should be emphasized that studies dealing with each individual within a household as opposed to the simple model of unitary household analysis would provide a better picture of welfare implications of modern agricultural technology, which is, however, a limitation of the present study.

The deprivation of the women is largely due to cultural construct of the farming society in Bangladesh and needs to be changed. The attitudinal change that is reflected in defining women's work at the national level, needs to be disseminated at all levels. One of the 
major vehicles for creating awareness against gender discrimination is in building up of human capital through gender sensitive literacy programs. NGOs already undertaking diversified programs independently in the rural regions can be entrusted with the task through a coordinated effort linking government and NGOs. Substantial collaboration between government agencies and some selected NGOs exists in other sectoral programs, such as, agroforestry, sericulture, poultry and livestock, and aquaculture development programs. However, evaluation of these collaborative efforts is limited.

The basic notion of balanced development requires that both men and women must be provided with equal opportunities in all spheres of life. The dominance of the agricultural sector in the Bangladesh economy indicates that attempts to bridge the gap in employment opportunity between men and women has to be sought in agricultural sector itself, as it engages the majority of the rural population, half of which are women. Therefore, suggestions to employ displaced rural women from the post-harvest processing sector to elsewhere in the economy seem to be seriously misdirected and unrealizable. Rather, policies for promoting agricultural diversification from foodgrain production to non-cereal crops will lead to increased absorption of hired women laborers in all stages of the production process, particularly, production of vegetables. However, this would require concomitant improvement in soil fertility and development of rural infrastructure in order to link remote regions with the urban markets. This would call for decentralized region-specific planning of agricultural development programs as opposed to the present day top down development activities.

Finally, it can be concluded that Bangladesh needs agricultural technologies that are labor-intensive and provide equal opportunities for men and women. Therefore, a decentralized agricultural crop diversification policy from foodgrain to non-cereal crop 
production which was found to employ more women would be a first step toward the goal of achieving gender equity on one hand and economic development on the other.

\section{NOTES}

1. The unit is Taka. One USD $=46.00$ taka approximately.

2. The notion is that the slow growth rate of agricultural labor force implies a movement towards a priori expectation of reaching a turning point in the growth of agricultural labor force. Such an occupational shift from agriculture to non-agriculture and/or modern sector implies the onset of a Lewisian transition of labor surplus economy.

3. These data were collected by BRAC (one of the largest national non-governmental organization) to serve as base-line information for a longitudinal study project, called as Village Study Project (VSP). The base-line data collection took about 6 months engaging 16 field researchers who were stationed in the core village of each thana. The first author of this study was responsible for coordinating the data collection team from the head office.

4. Land ownership categories are classified as follows: landless $=$ farmers not owning any land, marginal $=$ farmers owning land between $0.01-0.20$ ha, small $=$ farmers owning land between $0.21-1.00$ ha, medium = farmers owning land between $1.00-2.00$ ha, and large $=$ farmers owning land above 2 ha. $\mathrm{F}$-test was conducted to examine the difference between the land ownership distribution between two periods for the same region.

5. The crop groups are: local Aus rice, modern Aus rice, local Aman rice, modern Aman rice, local Boro rice, modern Boro rice, local wheat, modern wheat, jute, potato, pulses, spices, oilseeds, vegetables, and cotton. Pulses in turn include lentil, gram, chola, and khesari. Spices include onion, garlic, chilly, dhania, ginger, and termeric. Oilseeds include sesame, mustard, and groundnut. Vegetables include brinjal, cauliflower, cabbage, arum, beans, gourds, radish, and leafy vegetables.

6. The data for crop production activity includes labor input for each of the seven specific agricultural operations (e.g., seedbed and/or land preparation, sowing and/or transplanting, weeding, irrigation, fertilizer and pesticide application, harvesting, and threshing and/or winnowing operations).

7. A comparison of hired labor as percent of total labor between BIDS/IFPRI survey of crop year 1982 and present study reveals that the proportion increased from about 35 percent to 50 percent for local rice varieties and from 41 percent to 62 percent for modern rice varieties, respectively.

8. The index of infrastructure is constructed using the cost of access approach. A total of 13 elements are considered for its construction. These are, (1) primary market, (2) secondary market, (3) storage facility, (4) rice mill, (5) paved road, (6) bus stop, (7) bank, (8) union 
office, (9) agricultural extension office, (10) high school, (11) college, (12) thana (subdistrict) headquarter, and (13) post office. High index value refers to high under developed infrastructure.

9. The soil fertility index is constructed from test results of soil samples collected from the study villages during field survey for crop year 1996. Ten soil-fertility parameters were tested. These are: (1) soil $\mathrm{pH},(2)$ available nitrogen, (3) available potassium, (4) available phosphorus, (5) available sulfur, (6) available zinc, (7) soil texture, (8) cation exchange capacity (CEC) of soil, (9) soil organic matter content, and (10) electrical conductivity of soil. High index value refers to better soil fertility.

10. LIMDEP Software Version 6 (1992) is used for the analysis. 


\section{REFERENCES}

Abdullah, Tahrunnesa (1985). 'Women in Rice Farming in Bangladesh and How Technology Programs Can Reach Them'. In Women in Rice Farming. Proceedings of a Conference on Women in Rice Farming Systems. 26-30 September, 1983, International Rice Research Institute (IRRI), The Philippines. Gower Publishing Co. Ltd., Aldershot.

Agrawal, Bina (1994). A Field of One's Own: Gender and Land Rights in South Asia. Cambridge University Press, New York.

Ahmed, J.U. (1982). 'The Impact of New Paddy Post-Harvest Technology on the Rural Poor in Bangladesh'. In M. Greeley and M. Howes (eds) Rural Technology, Rural Institutions and The Rural Poorest. Bangladesh Academy for Rural Development, Comilla.

Ahmed, R., and M. Hossain (1990). Development Impact of Rural Infrastructure in Bangladesh. Research Report. No. 83. International Food Policy Research Institute, Washington, D.C.

Alauddin, M., and C. Tisdell (1991). The Green Revolution and Economic Development: The Process and its Impact in Bangladesh. Macmillan Publishers, London.

. (1995). 'Labor Absorption and Agricultural Development: Bangladesh's Experience and Predicament'. World Development. Vol. 23(2):281-97.

BBS. (1995). Statistical Yearbook of Bangladesh, 1995. Bangladesh Bureau of Statistics, Dhaka.

Begum, Saleha (1985). 'Women and Technology: Rice Processing in Bangladesh'. In Women in Rice Farming. Proceedings of a Conference on Women in Rice Farming Systems. 26-30 September, 1983, International Rice Research Institute (IRRI), The Philippines. Gower Publishing Co. Ltd., Aldershot.

Boserup, Ester (1989). Women's Role in Economic Development. Earthscan Publications. London.

BRAC (1993). BRAC Report, 1993. BRAC Centre, Dhaka.

Freebairn, D.K. (1995). 'Did the Green Revolution Concentrate Incomes? A Quantitative Study of Research Reports'. World Development. Vol. 23(2):265-79.

Hossain, M. (1989). Green Revolution in Bangladesh: Impact on Growth and Distribution of Income. University Press Limited, Dhaka.

Hossain, M., M.A. Quasem, M.M. Akash, and M.A. Jabber (1990). "Differential Impact of Modern Rice Technology: The Bangladesh Case". Working paper of Bangladesh Institute of Development Studies (BIDS)/ Bangladesh Rice Research Institute (BRRI). Dhaka. 
Mahmud, W., S.H. Rahman, and Sajjad Zohir (1994). "Agricultural Growth through Crop Diversification in Bangladesh". IFPRI Working Paper on Food Policy in Bangladesh, No. 7. International Food Policy Research Institute (IFPRI). Washington, D.C.

Osmani, S.R. (1990). 'Structural Change and Poverty in Bangladesh: The Case of a False Turning Point'. Bangladesh Development Studies. Vol. 18(3):55-74.

Sanyal, K.K. (1993). "Farm Level Fertilizer Use Survey: Report on the 1991-92 Aman Season". International Fertilizer Development Center (IFDC), Dhaka, Bangladesh.

Sen, A.K (1990). "Gender and Co-operative Conflicts". In Irene Tinker (ed.) Persistent Inequalities: Women and World Development. p129-34.

Shiva, V. (1991). The Violence of the Green Revolution: Third World Agriculture, Ecology and Politics. Zed Books, London.

Unnevehr, L.J., and M.L. Stanford (1985). 'Technology and the Demand for Women's Labor in Asian Rice Farming'. In Women in Rice Farming. Proceedings of a Conference on Women in Rice Farming Systems. 26-30 September, 1983, International Rice Research Institute (IRRI), The Philippines. Gower Publishing Co. Ltd., Aldershot.

Zaman, Habiba (1995). 'Patterns of Activity and Use of Time in Rural Bangladesh: Class, Gender, and Seasonal Variations'. Journal of Developing Areas. Vol. 29(3):371-388. 
Figure 3. Labor input in crop production by gender, 1989 (all regions).

\begin{tabular}{|c|c|c|c|c|c|c|c|c|}
\hline \multirow{3}{*}{$\begin{array}{c}\text { Crops/ } \\
\text { seasons }\end{array}$} & \multicolumn{7}{|c|}{ Proportion of total labor use per hectare of land $(\%)$} & \multirow{3}{*}{\begin{tabular}{|c|}
$\begin{array}{c}\text { Comparison } \\
\text { study }\end{array}$ \\
Total labor \\
\end{tabular}} \\
\hline & \multicolumn{2}{|c|}{ Family labor } & \multicolumn{2}{|c|}{ Hired labor } & \multicolumn{3}{|c|}{ Total labor } & \\
\hline & Men & Women & Men & Women & Men & Women & Total labor & \\
\hline \multicolumn{3}{|c|}{ Aus season (early monsoon) } & & & & & & \\
\hline L Aus rice & 43.1 & $\overline{11.1}$ & 45.1 & 0.7 & 88.2 & 11.8 & $100(153)$ & $152^{\mathrm{a}}$ \\
\hline M Aus rice & 35.0 & 11.5 & 52.9 & 0.6 & 87.9 & 12.1 & $100(174)$ & $185^{\mathrm{a}}$ \\
\hline Jute & 38.3 & 5.3 & 55.5 & 0.9 & 93.8 & 6.2 & $100(227)$ & $245^{\mathrm{b}}$ \\
\hline \multicolumn{3}{|c|}{ Aman Season (monsoon) } & & & & & & \\
\hline L Aman rice & 40.0 & 11.0 & 48.4 & 0.6 & 88.4 & 11.6 & $100(155)$ & $160^{\mathrm{b}}$ \\
\hline M Aman rice & 35.6 & 9.2 & 54.6 & 0.6 & 90.2 & 9.8 & $100(174)$ & $189^{\mathrm{b}}$ \\
\hline \multicolumn{3}{|c|}{ Boro Season (dry winter) } & & & & & & \\
\hline L Boro rice & 39.9 & 12.4 & 47.2 & 0.5 & 87.1 & 12.9 & $100(178)$ & $152^{\mathrm{a}}$ \\
\hline M Boro rice & 39.6 & 10.8 & 48.6 & 1.0 & 88.2 & 11.8 & $100(212)$ & $203^{a}$ \\
\hline L wheat & 46.2 & 16.1 & 35.6 & 2.1 & 81.8 & 18.2 & $100(143)$ & $146^{\mathrm{b}}$ \\
\hline M wheat & 44.1 & 13.2 & 41.2 & 1.5 & 85.3 & 14.7 & $100(136)$ & $159^{\mathrm{b}}$ \\
\hline Potato & 52.4 & 12.5 & 33.8 & 1.3 & 86.2 & 13.8 & $100(311)$ & $295^{\mathrm{b}}$ \\
\hline Pulses & 41.3 & 25.7 & 31.2 & 1.8 & 72.5 & 27.5 & $100(109)$ & $82^{b}$ \\
\hline Oilseeds & 38.5 & 18.3 & 40.4 & 2.8 & 78.9 & 21.1 & $100(109)$ & $118^{\mathrm{b}}$ \\
\hline Spices & 50.4 & 18.8 & 27.8 & 1.0 & 78.2 & 21.8 & $100(276)$ & $321^{\mathrm{b}}$ \\
\hline Vegetables & 34.9 & 46.5 & 17.4 & 1.2 & 52.3 & 47.7 & $100(186)$ & $217^{\mathrm{c}}$ \\
\hline Cotton & 50.1 & 15.3 & 23.1 & 11.5 & 73.2 & 26.8 & $100(295)$ & $211^{\mathrm{b}}$ \\
\hline
\end{tabular}

Note: Figures in parentheses are total number of labor used per hectare of land. L stands for Local and M stands for Modern.

${ }^{\text {a }}$ Selected from Hossain et al. (1990).

${ }^{\mathrm{b}}$ Selected from Mahmud et al. (1994).

${ }^{c}$ Selected from Sanyal (1993).

Source: BRAC-VSP Survey, 1990. 
Figure 4. Women's labor input by agricultural operations, crop year 1989 (all regions).

\begin{tabular}{l|c|c|c|c|c|c|c|c}
\hline \multirow{2}{*}{ Crops/Seasons } & \multicolumn{6}{c}{ Agricultural operations (percent of total female labor input) } \\
\cline { 2 - 8 } & $\begin{array}{c}\text { Land/ } \\
\text { seedbed } \\
\text { prepara- } \\
\text { tion }\end{array}$ & $\begin{array}{c}\text { Sowing/ } \\
\text { trans- } \\
\text { Planting }\end{array}$ & $\begin{array}{c}\text { Weed- } \\
\text { ing }\end{array}$ & $\begin{array}{c}\text { Irriga- } \\
\text { tion }\end{array}$ & $\begin{array}{c}\text { Fer- } \\
\text { tilizer } \\
\text { appli- } \\
\text { cation }\end{array}$ & $\begin{array}{c}\text { Harvest } \\
\text { Ing }\end{array}$ & $\begin{array}{c}\text { Thresh } \\
\text { Ing/ } \\
\text { post } \\
\text { harvest }\end{array}$ & $\begin{array}{c}\text { All } \\
\text { opera- } \\
\text { tions }\end{array}$ \\
\hline \multicolumn{2}{|c|}{ Aus season (early monsoon) } & & & & & & & \\
\hline Local Aus rice & - & - & 5.6 & - & - & 5.6 & 88.8 & 100 \\
Modern Aus rice & - & - & - & - & 5.0 & 5.0 & 90.0 & 100 \\
Jute & 7.2 & - & 7.2 & - & - & 7.1 & 78.5 & 100 \\
\hline Aman Season (monsoon) & & & & & & & \\
Local Aman rice & - & - & - & - & - & 5.6 & 94.4 & 100 \\
Modern Aman rice & - & - & - & - & - & 5.9 & 94.1 & 100 \\
\hline Boro Season (dry winter) & & & & & & & \\
Local Boro rice & - & 4.4 & - & 4.4 & - & 4.3 & 86.9 & 100 \\
Modern Boro rice & - & 4.0 & 4.0 & 4.0 & - & 4.0 & 84.0 & 100 \\
Local wheat & - & - & - & 3.8 & - & 7.7 & 88.5 & 100 \\
Modern wheat & - & - & - & - & - & 5.0 & 95.0 & 100 \\
Potato & 7.0 & 7.0 & 2.3 & 23.3 & - & 34.9 & 25.5 & 100 \\
Pulses & - & - & - & - & - & 10.0 & 90.0 & 100 \\
Oilseeds & - & - & - & - & - & 17.4 & 82.6 & 100 \\
Spices & 8.3 & 8.3 & 6.7 & 3.3 & - & 26.7 & 46.7 & 100 \\
Vegetables & 9.8 & 7.2 & 2.4 & 39.1 & 2.4 & 34.1 & 4.9 & 100 \\
Cotton & 7.6 & - & - & - & - & 70.9 & 21.5 & 100 \\
\hline
\end{tabular}

Note: Figures are percentages.

Source: BRAC-VSP Survey, 1990. 
Figure 5. Determinants of adoption of modern varieties of rice and wheat, crop year 1996.

\begin{tabular}{|c|c|c|c|c|c|c|}
\hline \multirow[t]{3}{*}{ Variables } & \multicolumn{4}{|c|}{$\begin{array}{c}\text { Present study } \\
\text { (Crop year, 1996) }\end{array}$} & \multirow{2}{*}{\multicolumn{2}{|c|}{$\begin{array}{c}\text { Comparison } \\
\text { (BIDS, Crop year 1987) } \\
\text { Tobit estimate } \\
\end{array}$}} \\
\hline & \multicolumn{2}{|c|}{ OLS estimate } & \multicolumn{2}{|c|}{ Tobit estimate } & & \\
\hline & Coefficients & t-ratio & Coefficients & t-ratio & Coefficients & t-ratio \\
\hline Constant & 0.115 & 0.887 & -0.090 & -0.404 & 33.500 & 1.49 \\
\hline OWNLND & -0.001 & -0.036 & 0.031 & 0.655 & -25.350 & $-4.76 * *$ \\
\hline IRRIG & 0.372 & $9.895 * * *$ & 0.542 & $8.234 * * *$ & 0.962 & $14.55 * * *$ \\
\hline RENT & 0.044 & 0.975 & 0.129 & 1.615 & 0.003 & 0.04 \\
\hline EDUCH & -0.004 & -1.357 & -0.008 & -1.377 & 1.620 & $2.28 * *$ \\
\hline LBR & -2.686 & -1.216 & -1.844 & -0.474 & 0.026 & 0.66 \\
\hline AMLND & -0.037 & $-1.861 *$ & -0.088 & $-2.636 * * *$ & -0.053 & -0.03 \\
\hline NAGINC & -0.001 & $-2.453 * *$ & -0.001 & $-1.733^{*}$ & na & na \\
\hline AGCRDIT & -0.001 & -0.990 & -0.001 & -0.374 & na & na \\
\hline INFRA & 0.006 & $7.487 * * *$ & 0.009 & $6.425 * * *$ & na & na \\
\hline SOIL & 0.117 & $1.890 *$ & 0.125 & 1.182 & na & na \\
\hline FP & -0.040 & -0.902 & 0.005 & 0.065 & -31.75 & $-1.95 * *$ \\
\hline WAGE & 0.009 & 0.886 & 0.004 & 0.216 & na & na \\
\hline ANMPRICE & 0.008 & $1.653^{*}$ & 0.017 & $2.106 * *$ & na & na \\
\hline FARMASET & 0.002 & $1.810^{*}$ & 0.002 & 1.277 & na & na \\
\hline FAMYSIZE & -0.003 & -0.590 & -0.005 & -0.567 & 2.63 & $1.75^{*}$ \\
\hline WORKING & 0.004 & 0.285 & 0.005 & 0.222 & na & na \\
\hline WORKWOM & -0.037 & $-1.861^{*}$ & -0.089 & $-2.359 * *$ & na & na \\
\hline Adj.R-squared & 0.36 & - & - & - & - & - \\
\hline $\mathrm{F}_{(17,388)}$ & $14.467 * * *$ & - & - & - & - & - \\
\hline Log-likelihood & - & - & -201.42 & - & -2748.00 & - \\
\hline
\end{tabular}

Note: $* * *=$ significant at 1 percent level $(\mathrm{p}<0.01)$.

$* *$ = significant at 5 percent level $(\mathrm{p}<0.05)$.

* = significant at 10 percent level $(\mathrm{p}<0.10)$.

na means not available.

Comparison data is selected from Hossain et al. (1990).

Source: Computed. 
Figure 6. Wage differentials by gender and region, crop year 1989 (all region).

\begin{tabular}{l|c|c|c|c}
\hline \multirow{2}{*}{ Regions } & \multicolumn{2}{|c|}{ Wage rate per day (taka) } & $\begin{array}{c}\text { Mean difference } \\
\text { between gender }\end{array}$ & t- ratio \\
\cline { 2 - 3 } & Men & Women & 11.5 & $16.356^{* * *}$ \\
\hline All region & 31.6 & 20.1 & 11.4 & $7.411^{* * *}$ \\
Jamalpur region & 32.8 & 21.4 & 11.0 & $15.130^{* * *}$ \\
Jessore region & 30.6 & 19.6 & - & - \\
\hline Mean difference & 2.2 & 1.8 & & - \\
between region & & & - & - \\
\hline F-value & $713.361^{* * *}$ & 1.449 & - & - \\
\hline Degree of freedom & 1,5012 & 1,183 & & \\
\hline
\end{tabular}

Note: $* * *=$ significant at 1 percent level $(\mathrm{p}<0.01)$.

Source: Computed. 
Figure 7. Determinants of labor demand in crop production, 1996.

\begin{tabular}{|c|c|c|c|c|c|}
\hline \multirow[t]{3}{*}{ Variables } & \multicolumn{3}{|c|}{$\begin{array}{c}\text { Present study } \\
\text { (Crop year 1996) }\end{array}$} & \multicolumn{2}{|c|}{$\begin{array}{c}\text { Comparison } \\
\text { (BIDS, Crop year 1982) }\end{array}$} \\
\hline & \multicolumn{2}{|c|}{$\begin{array}{l}\text { Demand for } \\
\text { hired labor }\end{array}$} & $\begin{array}{l}\text { Demand for } \\
\text { total labor }\end{array}$ & $\begin{array}{l}\text { Demand for } \\
\text { hired labor }\end{array}$ & $\begin{array}{l}\text { Demand for } \\
\text { total labor }\end{array}$ \\
\hline & OLS estimate & Tobit estimate & OLS estimate & Tobit estimate & OLS estimate \\
\hline Constant & $\begin{array}{c}162.780 \\
(7.537)^{* * *}\end{array}$ & $\begin{array}{c}170.900 \\
(7.453)^{* * *}\end{array}$ & $\begin{array}{c}155.420 \\
(6.941)^{* * *}\end{array}$ & $\begin{array}{c}56.2 \\
(2.16)^{* *}\end{array}$ & $\begin{array}{c}214.7 \\
(8.70)^{* * *}\end{array}$ \\
\hline AMLND & $\begin{array}{c}35.253 \\
(8.409)^{* * *}\end{array}$ & $\begin{array}{c}35.981 \\
(8.153)^{* * *}\end{array}$ & $\begin{array}{c}57.668 \\
(13.267)^{* * *}\end{array}$ & $\begin{array}{c}9.4 \\
(36.2)^{* * *}\end{array}$ & $\begin{array}{c}11.1 \\
(10.88)^{* * *}\end{array}$ \\
\hline MVAREA & $\begin{array}{c}29.231 \\
(5.415)^{* * *}\end{array}$ & $\begin{array}{c}29.694 \\
(5.226)^{* * *}\end{array}$ & $\begin{array}{c}16.000 \\
(2.859)^{* * *}\end{array}$ & $\begin{array}{c}29.5 \\
(17.40)^{* * *}\end{array}$ & $\begin{array}{c}46.9 \\
(17.68)^{* * *}\end{array}$ \\
\hline RENT & $\begin{array}{c}-15.560 \\
(-2.206)^{* *}\end{array}$ & $\begin{array}{l}-14.502 \\
(-1.790)^{*}\end{array}$ & $\begin{array}{c}29.185 \\
(3.666)^{* * * *}\end{array}$ & $\begin{array}{c}-2.9 \\
(-1.21)\end{array}$ & $\begin{array}{c}14.6 \\
(4.19)^{* * *}\end{array}$ \\
\hline WAGE & $\begin{array}{c}-1.007 \\
(-4.037)^{* * *}\end{array}$ & $\begin{array}{c}-1.065 \\
(-4.035)^{* * *}\end{array}$ & $\begin{array}{c}-1.502 \\
(-5.809)^{* * *}\end{array}$ & $\begin{array}{c}-2.81 \\
(-2.62)^{* * *}\end{array}$ & $\begin{array}{c}-9.20 \\
(-9.63) * * *\end{array}$ \\
\hline INFRA & $\begin{array}{l}-0.197 \\
(-1.594)\end{array}$ & $\begin{array}{c}-0.238 \\
(-1.818)^{*}\end{array}$ & $\begin{array}{c}0.267 \\
(2.088)^{* *}\end{array}$ & $\begin{array}{c}-0.96 \\
(-0.66)\end{array}$ & $\begin{array}{l}-1.56 \\
(1.22)\end{array}$ \\
\hline SOIL & $\begin{array}{c}-54.030 \\
(-5.852)^{* * *}\end{array}$ & $\begin{array}{c}-57.608 \\
(-5.860)^{* * *}\end{array}$ & $\begin{array}{c}-41.744 \\
(-4.361)^{* * *}\end{array}$ & na & na \\
\hline SUBP & $\begin{array}{c}-2.646 \\
(-2.313)^{* *}\end{array}$ & $\begin{array}{c}-3.027 \\
(-2.481)^{* * *}\end{array}$ & $\begin{array}{c}-2.794 \\
(-2.356)^{* *}\end{array}$ & na & na \\
\hline WORK & $\begin{array}{c}-5.780 \\
(-2.553)^{* * *}\end{array}$ & $\begin{array}{c}-6.083 \\
(-2.541)^{* * *}\end{array}$ & $\begin{array}{l}-0.248 \\
(-0.106)\end{array}$ & $\begin{array}{l}-3.10 \\
(0.84)\end{array}$ & $\begin{array}{c}17.78 \\
(4.08)^{* * *}\end{array}$ \\
\hline WORKW & $\begin{array}{l}1.218 \\
(0.357)\end{array}$ & $\begin{array}{l}1.575 \\
(0.436)\end{array}$ & $\begin{array}{c}-3.717 \\
(-1.050)\end{array}$ & $\begin{array}{l}-8.14 \\
(0.60)\end{array}$ & $\begin{array}{c}-24.77 \\
(-2.26)^{* * *}\end{array}$ \\
\hline EDUC & $\begin{array}{c}0.942 \\
(2.173)^{* *}\end{array}$ & $\begin{array}{c}1.096 \\
(2.388)^{* * *}\end{array}$ & $\begin{array}{c}0.541 \\
(1.204)\end{array}$ & $\begin{array}{c}5.37 \\
(4.64)^{* * *}\end{array}$ & $\begin{array}{c}3.30 \\
(2.97)^{* * *}\end{array}$ \\
\hline Adj. R-squared & 0.73 & - & 0.80 & - & 0.65 \\
\hline $\mathrm{F}_{(10,395)}$ & $111.43 * * *$ & - & $163.36 * * *$ & - & $107.4 * * *$ \\
\hline Log likelihood & - & -1886.42 & - & na & - \\
\hline
\end{tabular}

Note: Figures in parentheses are asymptotic t-ratios.

$* * *=$ significant at 1 percent level $(\mathrm{p}<0.01)$.

$* *=$ significant at 5 percent level $(\mathrm{p}<0.05)$.

$*$ = significant at 10 percent level $(p<0.10)$.

na means not available.

Comparison data is selected from Ahmed and Hossain (1990).

Source: Computed. 